\title{
FGF/FGFR Pathway Inhibitor E7090
}

National Cancer Institute

\section{Source}

National Cancer Institute. FGF/FGFR Pathway Inhibitor E7090. NCI Thesaurus. Code

C118672.

An inhibitor of the fibroblast growth factor (FGF)/fibroblast growth factor receptor (FGFR) pathway, with potential antineoplastic activity. Upon administration, the FGF/FGFR pathway inhibitor E7090 selectively interferes with the binding of FGF to FGFR through an as of yet not fully elucidated mechanism. This inhibits FGFR-mediated signaling and leads to both cell proliferation inhibition and cell death in FGFR-overexpressing tumor cells.

FGFR is a receptor tyrosine kinase essential to tumor cell proliferation, differentiation, and survival; its expression is upregulated in many tumor cell types. 